\title{
Monetary Transmission through Interest Rate Channel in Vietnam Before and After the Crisis
}

\author{
TRÀ̀M TH!̣ XUÂN HƯƠNG \\ University of Economics HCMC - txhuong@ueh.edu.vn \\ VÕ XUÂN VINH \\ University of Economics HCMC - vxvinh@gmail.com \\ NGUYẼ̃N PHÚC CẢNH
}

University of Economics HCMC - phuccanhnguyen.ueh@gmail.com

\section{ARTICLE INFO}

Article history:

Received:

Feb. 28, 2014

Received in revised form

Apr. 17, 2014

Accepted:

Sep. 30,2014

\section{Keywords:}

monetary policy, monetary

policy rates, market rate,

transmission
ABSTRACT

The paper employs the VAR model to examine the impact of monetary policy on the economy through interest rate channel (IRC) and levels of transmission before and after the 2008 crisis. The results indicate that in the period before the financial crisis, IRC exists in accordance with macroeconomic theory; however, the crisis period, in which increases in SBV monetary policy rates lead to increased inflation, has proved the existence of the cost channel of monetary transmission in Vietnam. 


\section{INTRODUCTION}

\subsection{Significance of the Study:}

Monetary policy plays a crucial role in the economy. It affects macroeconomic variables through transmission channels, among which interest rate channel (IRC) is considered an important and traditional one for monetary policy. A study of monetary transmission through IRC as well as changes in the transmission process resulted from economic crisis could allow the SBV to make timely adjustments to its operating mechanisms in accordance with the reality.

In addition, the study contributes more empirical evidence to theoretical foundations on monetary transmission in such a small and open economy as Vietnam.

\subsection{Subject Matter:}

The study focuses on monetary policy and particularly IRC in monetary transmission in Vietnam between 2000 and July 2013. Furthermore, it clarifies the impact of the 2008 financial crisis on monetary transmission through IRC, including lending rate and deposit rate offered by Vietnam's commercial banks.

\subsection{Research Objectives:}

Based on the aforementioned issues, the study features the following objectives:

- Examining the existence of IRC in monetary transmission in Vietnam through lending rate and deposit rate offered by commercial banks, and

- Investigating the changes in monetary transmission through IRC before and after the crisis.

\section{THEORETICAL BASES AND METHODOLOGY}

\subsection{Theoretical Background:}

Monetary policy refers to the actions taken by central banks to influence the money supply or interest rate of the economy (Lico Junior, 2008). With the aim of stabilizing price and promoting economic development, central banks employ such instruments of monetary policy as monetary policy rates, open market operations and required reserve ratio to exert influence on other economic variables. The process is termed as monetary transmission. Previous studies suggest that monetary transmission takes place through various channels, including interest rate channel, exchange rate channel, asset price channel, credit channel and expectation channel as the main ones (Mukherjee \& 
Bhattacharya, 2011; Dabla-Norris \& Floerkemeier, 2006; Mugume, 2011; Disyatat \& Vongsinsirikul, 2003; Ries, 2012; Honda, 2004; and others).

According to the Keynesian school of economics, IRC is the main transmission channel of monetary policy (Friedman, 1956), which is further confirmed by a study by Hannan \& Liang (1993), demonstrating the existence of IRC in the U.S. The issue is later discussed in such other studies as Taylor (1995) and Cecchetti (1995), substantiating the important role of IRC in monetary transmission. As explained in Keynesian theory, a change in monetary policy should lead to that in money supply, thereby changing the real interest rate and economic output (IS/LM model).

Increase in $M \rightarrow$ Decrease in $i_{r} \rightarrow$ Increase in $I \rightarrow$ Increase in $Y$

Where:

M: money supply

$i_{r}:$ real interest rate

I: investment

Y: output

Although Keynes highlights the fact that firm's investment decisions is determined by real interest rates, decisions on consuming essential, durable goods by households and individuals are also affected by changes in real interest rates. Thus, the interest rate transmission channel of monetary policy is influenced by shocks related to firm's investment and personal consumption of essential durable goods in the private sector.

The importance in monetary transmission through IRC is related to real interest rate rather than nominal one since the former would affect decisions on corporate investment and personal consumption. In addition, interest rate in consideration is the long-term one because the short-term rate exerts little impact on the decisions on corporate investment and personal consumption of durable goods in the private sector, which depend on long-term cash flow and benefits. Then, why are short-term rates main targets of the central bank? This could be explained by the term structure of interest rates and sticky prices. Suppose the central bank wants to expand the money supply, it would reduce short-term rates (the short-term sticky prices always lead to changes in a long term only), and short-term nominal interest rate would decrease.

According to the theory of the term structure of interest rates, long-term interest rate is the estimated future values of short-term ones; therefore, when the latter reduces, the 
former is expected to reduce accordingly (Buttiglone et al., 1997; Cook \& Haln, 1989; Evans \& Marshall, 1998; Favero et al., 1996; Haldane \& Read, 2000; Kuttner, 2001; Lindberg et al., 1997; and other studies). Reduced long-term rates stimulate investment and consumption of durable goods, thereby increasing the aggregate demand and output.

However, a recent study by Mengesha \& Holmes (2013) addresses an exception: No evidence for the existence of IRC in Eritrea, an African low-income economy, is found. The reason is that the country's financial system has yet to develop, therefore the commercial banking system almost dominates all operations of the economy, allowing such a credit channel of commercial banks to be indispensable. In Eritrea, the main tool of monetary policy is required reserve ratio; Bank of Eritrea also employs treasury bills as an instrument. In addition, the rediscount rate is not used as a monetary policy instrument in Eritrea. Since the rediscount window is inoperative and both the lending and deposit rates are rigid, the interest rate channel is ineffective (Mengesha \& Holmes, 2013). In some other countries such as Kenya, Uganda and Tanzania, the IRC does not play an important role in monetary transmission (Buigut, 2009), which also results from underdeveloped financial markets in these countries.

Ramlogan (2007) argues that monetary policy may affect various economic fields via interest rates and credit channels, and an effective transmission through IRC requires a developed financial market. In developed and highly competitive markets as in UK or the U.S., IRC is the most important channel (Engert et al., 1999; and Allen \& Gale, 2000, 2004), whereas in underdeveloped ones as in Trinidad Tibago, the credit channel is more important (Ramlogan, 2007). According to Romer \& Romer (1990), the transmission through IRC requires two conditions:

First, all commercial banks lack ability to hedge against changes in their reserve capital caused by changes in monetary policy.

Second, no other type of asset would replace cash as the means of payment.

In Vietnam today, the stock market has yet to develop; its supply of capital to the economy is not significant enough. Meanwhile, the system of commercial banks plays a crucial role in facilitating flows of capital while the outstanding loan compared to the GDP keeps growing over years (up to $123.1 \%$ by 2012) as illustrated in the following table: 
Table 1. Outstanding Loan of Vietnam's Commercial Bank System/GDP in 2007-2012(VND bil.)

\begin{tabular}{lcccccc}
\hline \multicolumn{1}{c}{ Year } & $\mathbf{2 0 0 7}$ & $\mathbf{2 0 0 8}$ & $\mathbf{2 0 0 9}$ & $\mathbf{2 0 1 0}$ & $\mathbf{2 0 1 1}$ & $\mathbf{2 0 1 2}$ \\
\hline GDP & $1,096,780$ & $1,400,693$ & $2,039,686$ & $2,689,527$ & $3,062,549$ & $3,276,927$ \\
Outstanding Loan & $1,143,715$ & $1,485,038$ & $1,658,389$ & $1,980,914$ & $2,535,008$ & $2,662,519$ \\
As \% of GDP & $95.9 \%$ & $94.3 \%$ & $123.0 \%$ & $135.8 \%$ & $120.8 \%$ & $123.1 \%$ \\
\hline
\end{tabular}

Source: ADB (2013), Vietnam Key Indicators.

In addition to that, Vietnam is an open economy with high demand for cash and annual growth of money supply is commonly high even though it tends to decrease in 2011 and 2012.

Figure 1. Growth Rate of M2 in Vietnam in 2007 - 2012

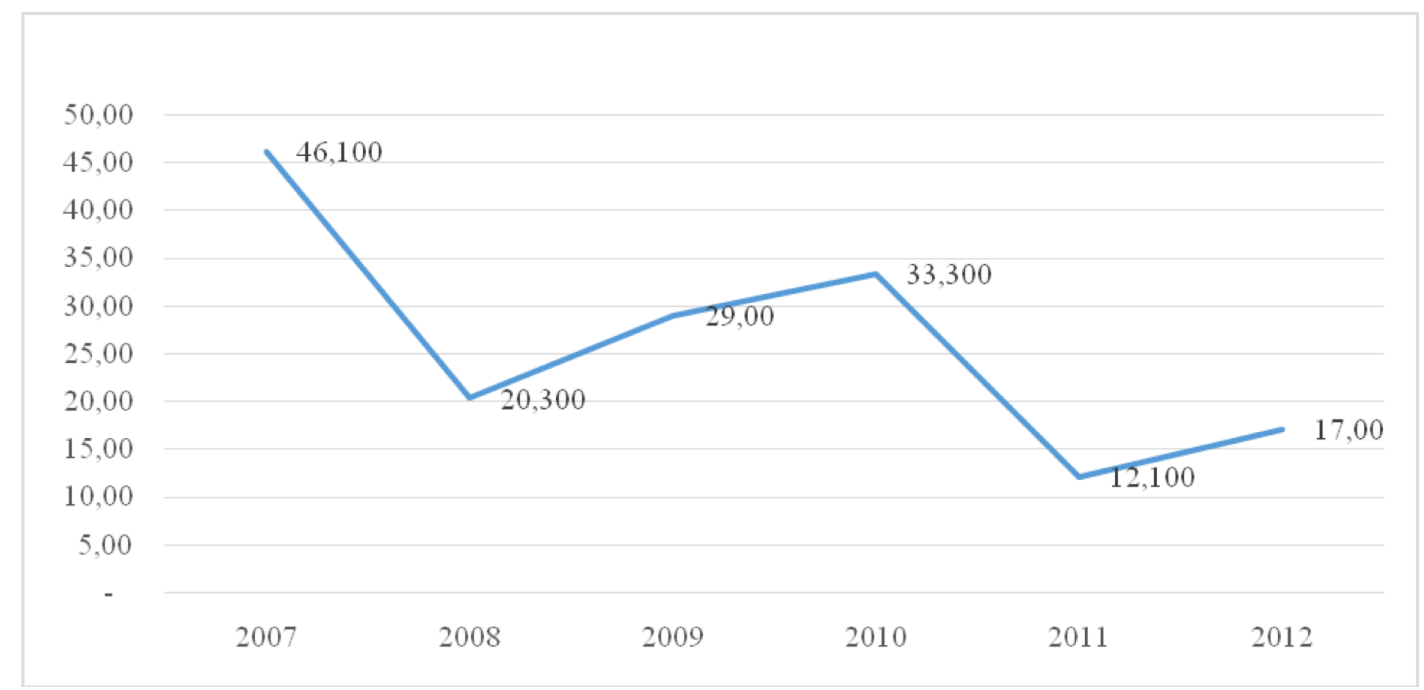

Source: ADB (2013), Vietnam Key Indicators.

Accordingly, macroeconomic conditions show that IRC can exist and act as an important transmission channel of monetary policy. On such basis, the research concerns the transmission channel through market rates (lending and borrowing rates) offered by commercial banks and further evaluates the impact of financial crisis on the transmission through IRC, phased over the two periods: 2000-2007 (before the crisis) and 2008-2013 (after the crisis).

\subsection{Data and Methodology:}




\section{Research model:}

The VAR (Vector Autoregression) model introduced by Sims (1980) is widely applied by macroeconomists to quantify the dynamic response of a group of macroeconomic variables without demanding powerful conditions to identify macro shocks. VAR model then became one of the most common models to be applied to time series data. VAR model is used to measure the dependence and linear correlations between various variables of time series data, especially in measuring interactions between macro variables of time series data since such macroeconomic data, according to Sims (1980), have the following characteristics:

- Macroeconomic factors often come up with autocorrelation; thus, values of previous periods tend to affect those of current ones. The autocorrelation usually makes macro variables fluctuate and have some lag orders.

- Macro variables often interact in a network model, i.e. all variables interact with one another in the form of network; therefore, any macro variable can be affected by the others and vice versa.

A change in monetary policy influences market rate and subsequently, other variables in the economy; however, as responses of the variables to the policy-related shocks are different, it is important that levels as well as length of the responses be well clarified. Additionally, researchers may need to predict future variance of the studied variables to adequately demonstrate the impacts of shocks on the predicted future variance of the variable and offer control solutions. VAR model provides two tools for dealing with the issue: Impulse response function (IRF) helps measure the degree of response as well as lag order of the response of the studied variable to shocks in other variables, and variance decomposition supports the analysis of contribution from factors to prediction of variation of variance of future studied variables.

To examine the transmission mechanism of monetary policy through IRC in Vietnam, the VAR (Vector AutoRegression) model applied by Bernanke \& Blinder (1992), Sims (1980, 1992) and many others is employed in this study. Specifically, when the monetary policy produces impacts through the interest rate channel, such impacts will be transmitted from monetary policy rates to lending and borrowing rates. VAR features the following form:

$$
y_{t}=B(L) y_{t}+u_{t}
$$


where: $\mathrm{y}_{\mathrm{t}}$ is a vector $\mathrm{n} \times 1$ of economic variables, including the following variables in order: VNIBOR (inter-bank average interest rate - SBV), LER (average lending rate of commercial banks - SBV) or DER (average deposit rate of commercial banks SBV), CPI (consumer price index - IMF); B(L) is structure matrix of lagged variables to $\mathrm{k}$; and $\mathrm{u}_{\mathrm{t}}$ is vector $\mathrm{n} \mathrm{x} 1$ of errors.

However, policy rate and market rate often respond in the same direction, thereby being possibly cointegrated. Stationarity and cointegration are tested to figure out whether the data are suitable for VAR model. If the latter exists, VECM model is employed instead of VAR. According to Friedman (1956), an increase in policy rate will bring about that in market rate (including borrowing and lending rates of commercial banks) and transmission reduces investment and inflation accordingly. In brief, the expected relationship between monetary policy rates and market rates is positive and between these and the one with inflation is negative.

\section{Data:}

The data are collected from SBV (inter-bank average rate) and GSO (CPI) and IMF (average lending rate and average borrowing rate) from January 2000 to July 2013. Regarding policy interest rates, there are three types in Vietnam: inter-bank average rate (VNIBOR), refinancing rate and rediscount rate; however, the second and third types are not efficient while operations in inter-bank market is the main channel in implementing the monetary policy. Therefore, the first type is employed by the authors of this study in the context of Vietnam as a representative of monetary policy rates. This practice is very common among many central banks in the world (Disyatat \& Vongsinsirikul, 2003).

Applying VAR model to the two periods (before and after the crisis), the authors collected monthly data and investigate the monetary transmission in Vietnam through lending and borrowing rates of commercial banks to inflation.

Data is described statistically in Table 2.

Table 2. Statistical Description of Data

\begin{tabular}{|c|c|c|c|c|}
\hline Variable/Criterion & VNIBOR & LER & DER & CPI \\
\hline \multicolumn{5}{|l|}{ January 2000 - December 2007} \\
\hline Mean & 6.730625 & 10.20292 & 6.308229 & 4.581431 \\
\hline Median & 6.855000 & 10.20000 & 6.540000 & 4.501648 \\
\hline
\end{tabular}




\begin{tabular}{|c|c|c|c|c|}
\hline Max & 8.740000 & 11.40000 & 7.680000 & 12.54776 \\
\hline Min & 5.180000 & 8.460000 & 3.540000 & -2.739748 \\
\hline Standard deviation & 0.771388 & 0.902285 & 1.271599 & 3.959221 \\
\hline Skewness & -0.211485 & -0.296374 & -0.942552 & -0.314421 \\
\hline Kurtosis & 2.574286 & 1.743131 & 2.901517 & 1.920458 \\
\hline Jarque-Bera & 1.440545 & 7.724278 & 14.25327 & 6.243411 \\
\hline P-value & 0.486620 & 0.021023 & 0.000803 & 0.044082 \\
\hline Obs. & 96 & 96 & 96 & 96 \\
\hline \multicolumn{5}{|c|}{ January 2008 - July 2013} \\
\hline Mean & 9.912090 & 14.80551 & 10.47895 & 12.64978 \\
\hline Median & 8.900000 & 14.60000 & 10.85000 & 10.52070 \\
\hline $\operatorname{Max}$ & 17.57000 & 20.25000 & 17.16000 & 28.35694 \\
\hline Min & 3.620000 & 10.07000 & 6.540000 & -5.830000 \\
\hline Standard deviation & 3.385513 & 2.795319 & 2.635734 & 7.662913 \\
\hline Skewness & 0.294703 & 0.135555 & 0.619814 & 0.367557 \\
\hline Kurtosis & 2.268128 & 2.029339 & 3.006548 & 2.364152 \\
\hline Jarque-Bera & 2.465140 & 2.835452 & 4.290009 & 2.637276 \\
\hline P-value & 0.291542 & 0.242264 & 0.117068 & 0.267499 \\
\hline Obs. & 67 & 67 & 67 & 67 \\
\hline
\end{tabular}

Source: Authors' calculations

The values of monetary policy rates, lending rate, borrowing rate and inflation after the crisis are all higher than those before the crisis.

Description of the test for the stationarity of the data is illustrated in Table 3. 
Table 3. Unit Root Tests on the Dataset

\begin{tabular}{|c|c|c|c|c|c|}
\hline \multirow[t]{2}{*}{ Variable } & \multicolumn{2}{|c|}{$\begin{array}{c}\text { Dickey - Fuller unit root } \\
\text { test (zero-order) }\end{array}$} & \multicolumn{2}{|c|}{$\begin{array}{c}\text { Dickey - Fuller unit root } \\
\text { test (first-order) }\end{array}$} & \multirow[t]{2}{*}{ Conclusion } \\
\hline & $T$ - statistic & $P$-value & $T-$ statistic & $P$-value & \\
\hline \multicolumn{6}{|c|}{ January 2000 - December 2007} \\
\hline VNIBOR & -3.004489 & 0.0380 & & & Zero-order stationary \\
\hline LER & -1.001428 & 0.7503 & -8.956079 & 0.0000 & First-order stationary \\
\hline DER & -2.089629 & 0.2493 & -8.844660 & 0.0000 & First-order stationary \\
\hline CPI & -0.426920 & 0.8991 & -5.015976 & 0.0001 & First-order stationary \\
\hline \multicolumn{6}{|c|}{ January 2008 - July 2013} \\
\hline VNIBOR & -1.732664 & 0.4104 & -9.811286 & 0.0000 & First-order stationary \\
\hline LER & -2.638637 & 0.0906 & -5.416370 & 0.0000 & First-order stationary \\
\hline DER & -2.974987 & 0.0426 & & & Zero-order stationary \\
\hline CPI & -1.480353 & 0.5374 & -3.947427 & 0.0033 & First-order stationary \\
\hline
\end{tabular}

Source: Results collected from Eviews 6.

The results of unit root tests show that the variables have different order of stationarity; therefore, the difference of variables that are first-order stationary is needed while other variables that are zero-order stationary are kept intact and VAR model is applied. New symbols for the variables and data processing are presented in Table 4.

Table 4. Data Processing for VAR Model

\begin{tabular}{llll}
\hline \multicolumn{1}{c}{ Variable } & \multicolumn{1}{c}{ Conclusion } & \multicolumn{1}{c}{ Process } & \multicolumn{1}{c}{ New symbol } \\
\hline January 2000-December & 2007 & & \\
VNIBOR & Zero-order stationary & Intact & VNIBOR \\
LER & First-order stationary & First-order difference & DLER \\
DER & First-order stationary & First-order difference & DDER \\
CPI & First-order stationary & First-order difference & DCPI \\
\hline
\end{tabular}

January 2008 - July 2013 
VNIBOR

LER

DER

CPI

$\begin{array}{lll}\text { First-order stationary } & \text { First-order difference } & \text { DVNIBOR } \\ \text { First-order stationary } & \text { First-order difference } & \text { DLER } \\ \text { Zero-order stationary } & \text { Intact } & \text { CDER } \\ \text { First-order stationary } & \text { First-order difference } & \text { DCPI }\end{array}$

Source: Authors' calculations from Eviews 6.

To determine the relationships between the variables before including them in the VAR model, Granger causality test is conducted with results presented in Table 5.

Table 5: Results of Granger Causality Tests

\begin{tabular}{|c|c|c|c|c|}
\hline \multirow{2}{*}{ Variable } & \multicolumn{2}{|c|}{$\begin{array}{c}\mathrm{H0}_{1} \text { : VNIBOR does not Granger- } \\
\text { cause other variables }\end{array}$} & \multicolumn{2}{|c|}{$\begin{array}{c}\mathrm{HO}_{2}: \text { Variables do not Granger- } \\
\text { cause DCPI }\end{array}$} \\
\hline & F-Statistic & p-value & F-Statistic & p-value \\
\hline \multicolumn{5}{|c|}{ January 2000 - December 2007} \\
\hline DLER & 2.94829 & 0.0249 & 2.82251 & 0.0301 \\
\hline DDER & 6.25726 & 0.0002 & 1.55300 & 0.1947 \\
\hline DCPI & 1.23021 & 0.3045 & & \\
\hline \multicolumn{5}{|c|}{ January 2008 - July 2013} \\
\hline DLER & 0.87670 & 0.5077 & 2.73097 & 0.0365 \\
\hline DER & 2.11642 & 0.0787 & 1.19360 & 0.3258 \\
\hline DCPI & 1.31874 & 0.2714 & & \\
\hline
\end{tabular}

Source: Authors' calculations with Eviews 6.

The results of the Granger causality tests indicates that on the one hand, in the period before the crisis, VNIBOR exerts a significantly strong impact on lending and borrowing rates but does not affect CPI. Of lending and borrowing rates, only the former affects inflation. On the other hand, after the crisis (2008 - July 2013), monetary policy rates affect the borrowing rate, whereas the latter does not affect inflation anymore. In the next section, VAR model is used for testing and clarifying this fact.

\section{RESULTS AND DISCUSSION}

\subsection{VAR Model Applied to the Period Before the Crisis:}


Lag order of monthly data from January 2000 to December 2007 is tested according to Lag Length Criteria prepared by Eviews 6 and the appropriate lag order of 4 is found.

\section{Table 6. Selection of Lag Order Criteria for VAR}

Model with DLER

\begin{tabular}{ccccccc}
\hline Lag & LogL & LR & FPE & AIC & SC & HQ \\
\hline 0 & -183.1678 & NA & 0.021080 & 4.654194 & 4.743520 & 4.690008 \\
1 & -19.66115 & 310.6626 & 0.000443 & 0.791529 & $1.148833^{*}$ & $0.934782^{*}$ \\
2 & -11.65206 & 14.61658 & 0.000455 & 0.816302 & 1.441583 & 1.066995 \\
3 & 4.115504 & 27.59324 & 0.000385 & 0.647112 & 1.540372 & 1.005246 \\
4 & 16.01460 & $19.93098^{*}$ & $0.000360^{*}$ & $0.574635^{*}$ & 1.735873 & 1.040209 \\
5 & 21.51446 & 8.799775 & 0.000396 & 0.662139 & 2.091355 & 1.235152 \\
6 & 24.65558 & 4.790215 & 0.000463 & 0.808610 & 2.505804 & 1.489064 \\
7 & 30.58228 & 8.593717 & 0.000508 & 0.885443 & 2.850615 & 1.673337 \\
8 & 33.29447 & 3.729265 & 0.000608 & 1.042638 & 3.275788 & 1.937972 \\
\hline
\end{tabular}

* indicates lag order selected by the criterion

Model with DDER

\begin{tabular}{ccccccc}
\hline Lag & LogL & LR & FPE & AIC & SC & HQ \\
\hline 0 & -185.3672 & NA & 0.022271 & 4.709179 & 4.798505 & 4.744992 \\
1 & -1.777916 & 348.8196 & $0.000283^{*}$ & $0.344448^{*}$ & $0.701752^{*}$ & $0.487701^{*}$ \\
2 & 3.921797 & 10.40198 & 0.000308 & 0.426955 & 1.052237 & 0.677649 \\
3 & 14.37728 & 18.29709 & 0.000298 & 0.390568 & 1.283828 & 0.748702 \\
4 & 24.96501 & $17.73446^{*}$ & 0.000288 & 0.350875 & 1.512113 & 0.816448 \\
5 & 31.18298 & 9.948744 & 0.000311 & 0.420426 & 1.849642 & 0.993439 \\
6 & 42.19385 & 16.79159 & 0.000299 & 0.370154 & 2.067348 & 1.050607 \\
7 & 49.96637 & 11.27014 & 0.000313 & 0.400841 & 2.366013 & 1.188735 \\
8 & 57.27016 & 10.04271 & 0.000334 & 0.443246 & 2.676396 & 1.338580 \\
\hline
\end{tabular}

Source: Authors' calculations employing Eviews 6. 
Model VAR (4) applied to lending rate and borrowing rate in turn gives the following results:

Table 7. Results of VAR with DLER and DDER

\begin{tabular}{|c|c|c|c|}
\hline Independent variable & VNIBOR & DLER & DCPI \\
\hline Intercept & $1.351096^{* *}$ & -0.174824 & $1.166512 *$ \\
\hline VNIBOR(-1) & $0.876550 * * *$ & 0.060213 & 0.004339 \\
\hline VNIBOR(-2) & -0.018843 & 0.053337 & -0.130871 \\
\hline VNIBOR(-3) & -0.030246 & 0.007239 & 0.017052 \\
\hline VNIBOR(-4) & -0.025182 & $-0.096470^{*}$ & -0.049249 \\
\hline DLER(-1) & 0.087119 & 0.044626 & -0.379333 \\
\hline DLER(-2) & 0.260323 & -0.022291 & 0.036820 \\
\hline $\operatorname{DLER}(-3)$ & $-0.641016^{* * *}$ & -0.012906 & $-0.430152^{*}$ \\
\hline DLER(-4) & 0.173187 & 0.097506 & $0.545084 *$ \\
\hline DCPI(-1) & $0.194354 *$ & 0.003966 & $0.351262 * *$ \\
\hline DCPI(-2) & 0.077167 & 0.067680 & 0.067109 \\
\hline DCPI(-3) & -0.153400 & $-0.112891 * *$ & 0.149941 \\
\hline DCPI(-4) & -0.054422 & $0.123500 * *$ & -0.057620 \\
\hline Independent variable & VNIBOR & DDER & DCPI \\
\hline Intercept & $1.482934 * *$ & -0.072406 & $1.405239 * *$ \\
\hline VNIBOR(-1) & $0.829780 * * *$ & $0.125833 * * *$ & -0.104139 \\
\hline VNIBOR(-2) & -0.007606 & 0.023903 & 0.042279 \\
\hline VNIBOR(-3) & 0.052112 & -0.033125 & 0.019638 \\
\hline VNIBOR(-4) & -0.091792 & $-0.101962 *$ & -0.148849 \\
\hline $\operatorname{DDER}(-1)$ & 0.047332 & -0.060712 & $-0.646079 * *$ \\
\hline $\operatorname{DDER}(-2)$ & -0.171210 & -0.008337 & -0.093690 \\
\hline DDER(-3) & 0.063358 & 0.126729 & 0.127175 \\
\hline $\operatorname{DDER}(-4)$ & 0.070027 & -0.056493 & 0.085351 \\
\hline
\end{tabular}




$\begin{array}{llll}\text { DCPI(-1) } & 0.137060 & -0.034447 & 0.306412 * * \\ \text { DCPI(-2) } & 0.149926 & 0.008361 & 0.112880 \\ \text { DCPI(-3) } & -0.125429 & 0.100865^{*} & 0.096483 \\ \text { DCPI(-4) } & -0.084651 & -0.028436 & -0.012423\end{array}$

$*, * *$, and $* * *$ denote significance at $10 \%, 5 \%$, and $1 \%$ respectively

Source: Results from Eviews 6.

The results yielded by VAR model suggest that average inter-bank rate has impact on borrowing and lending rates, whereas borrowing rate affects inflation. A stability test for the two models shows that they satisfy the stability condition.

Table 8. AR Root Tests

\begin{tabular}{cc}
\hline Root of VAR Model with DLER & Modulus \\
\hline 0.832843 & 0.832843 \\
$0.637952-0.423898 \mathrm{i}$ & 0.765946 \\
-0.757095 & 0.765946 \\
$0.027719-0.752262 \mathrm{i}$ & 0.757095 \\
$0.027719+0.752262 \mathrm{i}$ & 0.752773 \\
$-0.406720-0.629849 \mathrm{i}$ & 0.752773 \\
$-0.406720+0.629849 \mathrm{i}$ & 0.749754 \\
$0.601209-0.182688 \mathrm{i}$ & 0.749754 \\
$0.601209+0.182688 \mathrm{i}$ & 0.628353 \\
-0.390302 & 0.628353 \\
-0.133328 & 0.390302 \\
\hline $0.657885+0.206016 \mathrm{i}$ & 0.133328 \\
\hline 0.766866 & Modulus \\
\hline Root of VAR Model with DDER & 0.766866 \\
\hline $0.65865016 \mathrm{i}$ & 0.689388 \\
\hline
\end{tabular}




$\begin{array}{cc}-0.388646-0.542145 i & 0.667058 \\ -0.388646+0.542145 i & 0.667058 \\ 0.508407-0.426289 i & 0.663475 \\ 0.508407+0.426289 i & 0.663475 \\ -0.435167-0.371895 i & 0.572430 \\ -0.435167+0.371895 i & 0.572430 \\ -0.048309-0.454846 i & 0.457404 \\ -0.048309+0.454846 i & 0.457404 \\ -0.279729 & 0.279729\end{array}$

No root lies outside the unit circle, VAR model satisfies the stability condition

Source: Results from Eviews 6.

The LM Test on VAR model indicates that the model no longer reveals autocorrelation, therefore it is considered appropriate.

Table 9. LM Tests on VAR Model

Model with DLER

\begin{tabular}{ccc}
\hline Lags & LM-Stat & Prob \\
\hline 1 & 6.318360 & 0.7077 \\
2 & 7.681186 & 0.5666 \\
3 & 3.916581 & 0.9168 \\
4 & 4.121039 & 0.9033 \\
5 & 10.07112 & 0.3448 \\
6 & 9.849230 & 0.3628 \\
7 & 4.845651 & 0.8476 \\
8 & 11.69143 & 0.2313 \\
9 & 9.207662 & 0.4183 \\
10 & 11.21679 & 0.2611 \\
11 & 6.336638 & 0.7058
\end{tabular}


0.3944

Model with DDER

\begin{tabular}{ccc}
\hline Lags & LM-Stat & Prob \\
\hline 1 & 9.436887 & 0.3980 \\
2 & 10.37316 & 0.3211 \\
3 & 13.48707 & 0.1418 \\
4 & 8.144409 & 0.5197 \\
5 & 12.47927 & 0.1876 \\
6 & 19.31205 & 0.0227 \\
7 & 8.576477 & 0.4773 \\
8 & 10.80499 & 0.2893 \\
9 & 8.053794 & 0.5287 \\
10 & 4.451709 & 0.8793 \\
11 & 5.263013 & 0.8108 \\
12 & 4.969552 & 0.8370 \\
\hline
\end{tabular}

Source: Results from Eviews 6.

Applying the impulse response function to test monetary transmission through IRC to inflation yields results for DLER and DDER, illustrated in Figures 2 and 3 respectively. 
Figure 2. Impulse Response Function for VAR with DLER

Response to Cholesky One S.D. Innovations \pm 2 S.E.

Response of DLER to VNIBOR

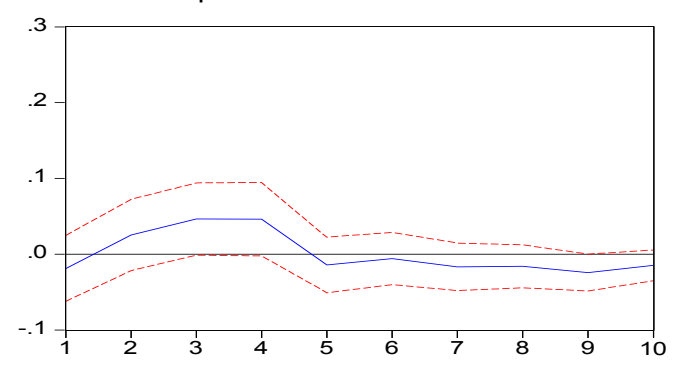

Response of DLER to DCPI

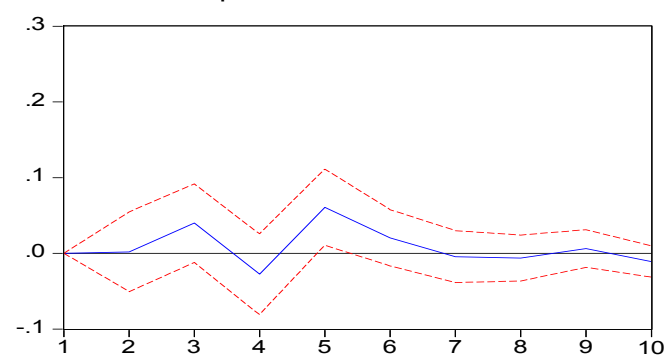

Response of DCPI to DLER

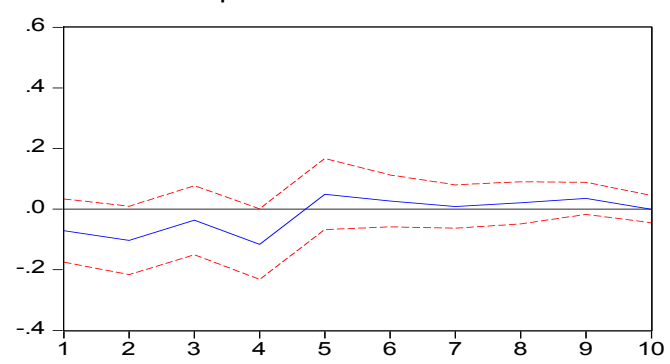

Response of DLER to DLER

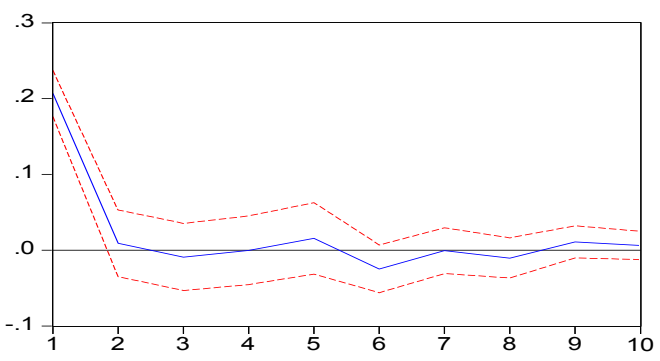

Response of DCPI to VNIBOR

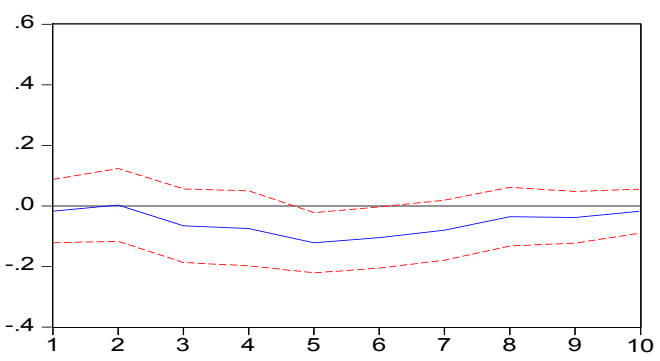

Response of DCPI to DCPI

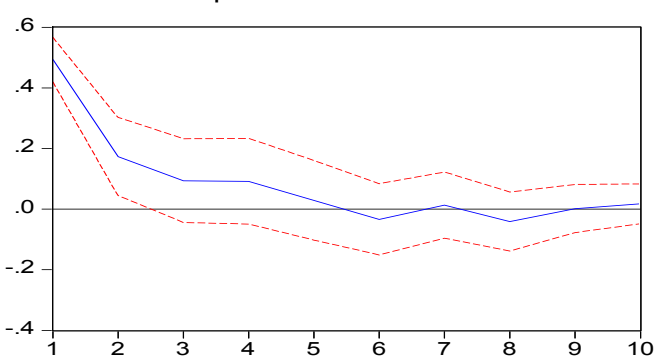

Source: IRF Results from Eviews 6.

The results of impulse response function suggest that lending rate responds positively to the shock caused by increases in monetary policy rates (namely VNIBOR) and with the lag of one month, which reflects the role played by IRC in monetary transmission in Vietnam before the crisis. In contrast, inflation has an immediate response to the shock caused by a higher lending rate and a two-month lagged response to the monetary policy rates. Thus, it can be concluded that in Vietnam, IRC exists in the period before the crisis through lending rate. An increase in 
monetary policy rates will boost lending rate and control inflation, and the transmission from policy rates to lending rate experiences a lag length of one month and a two-month lag to inflation. The transmission process, however, ends after a lapse of five months.

\section{Figure 3. Impulse Response Function for VAR with DDER}
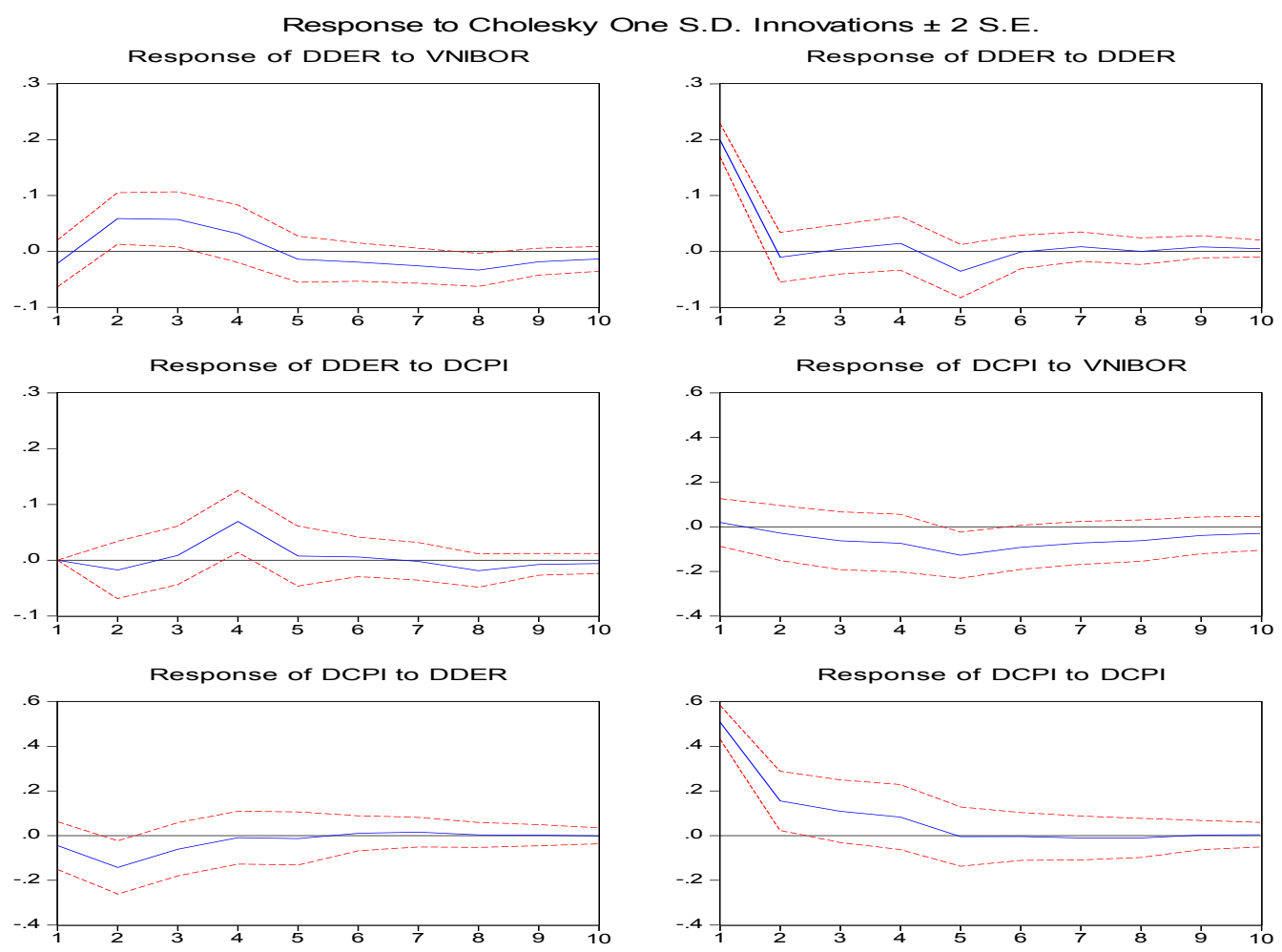

Source: IRF Results from Eviews 6.

Through borrowing rate channel, monetary transmission transpires faster, and response of inflation is similar to that to the lending rate channel. Yet, the process would be faster and end more quickly when response from CPI stops in the fourth month.

Accordingly, before the crisis, IRC exists in both lending and borrowing rates, whereas the response of borrowing rate takes place and ceases faster than that from lending rate. To examine IRC after the crisis, VAR is applied to the dataset from January 2008 to December 2010, the results of which is presented in the next section. 


\subsection{VAR Model Applied to the Period after the Crisis:}

A test of lag criteria reveals that a lag order of 2 is appropriate.

Table 10. Selection of Lag Criteria for VAR

Model with DLER

\begin{tabular}{ccccccc}
\hline Lag & LogL & LR & FPE & AIC & SC & HQ \\
\hline 0 & -386.9105 & NA & 88.53478 & 12.99702 & 13.10173 & 13.03798 \\
1 & -306.8547 & 149.4376 & 8.293336 & 10.62849 & $11.04736^{*}$ & $10.79233^{*}$ \\
2 & -294.6712 & $21.52408^{*}$ & $7.477851^{*}$ & $10.52237^{*}$ & 11.25540 & 10.80910 \\
3 & -291.6027 & 5.114283 & 9.169423 & 10.72009 & 11.76726 & 11.12970 \\
4 & -283.7915 & 12.23749 & 9.650609 & 10.75972 & 12.12104 & 11.29221 \\
5 & -278.8226 & 7.287739 & 11.24683 & 10.89409 & 12.56956 & 11.54946 \\
6 & -272.7870 & 8.248586 & 12.76743 & 10.99290 & 12.98253 & 11.77115 \\
\hline & & & Model with DER & & \\
\hline Lag & LogL & LR & FPE & AIC & SC & HQ \\
\hline 0 & -231.3628 & NA & 14.10502 & 11.16013 & 11.28425 & 11.20563 \\
1 & -178.8844 & 94.96091 & 1.782186 & 9.089735 & $9.586212^{*}$ & 9.271713 \\
2 & -164.2626 & $24.36971^{*}$ & 1.374121 & 8.822029 & 9.690864 & $9.140491 *$ \\
3 & -159.7099 & 6.937446 & 1.730008 & 9.033805 & 10.27500 & 9.488751 \\
4 & -149.4572 & 14.15846 & 1.687912 & 8.974154 & 10.58770 & 9.565584 \\
5 & -138.5171 & 13.54487 & 1.631439 & 8.881769 & 10.86768 & 9.609683 \\
\hline 6 & -123.7218 & 16.20442 & 1.355299 & 8.605800 & 10.96407 & 9.470198 \\
\hline & & & & & & \\
\hline & & & & & & \\
\hline
\end{tabular}

Source: Results from Eviews 6.

VAR(2) is designed for DLER and DER in the period 2008-2013 with the results illustrated in Table 11.

Table 11. Results of VAR Model for DLER and DER

\begin{tabular}{lccc}
\hline Independent variable & DVNIBOR & DLER & DCPI \\
\hline DVNIBOR(-1) & -0.239410 & 0.008004 & $0.196759^{*}$
\end{tabular}




\begin{tabular}{lccc} 
DVNIBOR(-2) & 0.221048 & 0.040397 & 0.070792 \\
DLER(-1) & -0.207617 & $0.786543 * * *$ & $-0.768641^{* * *}$ \\
DLER(-2) & 0.092306 & 0.107540 & $0.808953 * * *$ \\
DCPI(-1) & $0.318127 *$ & 0.085457 & $0.609181 * * *$ \\
DCPI(-2) & -0.076984 & -0.069374 & 0.178558 \\
C & 1.302695 & 1.102546 & -0.541259 \\
\hline & DVNIBOR & DER & DCPI \\
\hline DVNIBOR(-1) & $-0.429643 * * *$ & $0.181259 * *$ & 0.345184 \\
DVNIBOR(-2) & 0.053646 & $0.224773 * *$ & 0.254756 \\
DER(-1) & $0.376141^{* *}$ & $1.112148 * * *$ & 0.272709 \\
DER(-2) & $-0.580011^{* * *}$ & $-0.284932 * *$ & -0.274817 \\
DCPI(-1) & $0.203236 * * *$ & $0.074357 *$ & -0.174697 \\
DCPI(-2) & 0.106512 & 0.051410 & 0.129982 \\
C & $2.164341^{* * *}$ & $1.848095 * * *$ & -0.076726 \\
\hline$* * *$ & & &
\end{tabular}

$*, * *$, and $* * *$ denote significance at $10 \%, 5 \%$, and $1 \%$ respectively

Source: Results from Eviews 6.

The results of the AR root tests for stability of the model shows that both models satisfy stability requirement.

Table 12. Tests of the Models' Stability

\begin{tabular}{cc}
\hline Root of VAR with DLER & Modulus \\
\hline 0.927041 & 0.927041 \\
0.847907 & 0.847907 \\
-0.610904 & 0.610904 \\
0.356204 & 0.356204 \\
$-0.181967-0.215415 \mathrm{i}$ & 0.281985 \\
$-0.181967+0.215415 \mathrm{i}$ & 0.281985 \\
\hline
\end{tabular}

No root lies outside the unit circle, this VAR model satisfies the stability condition 
Root of VAR with DLER

$$
\begin{gathered}
0.808123-0.300660 \mathrm{i} \\
0.808123+0.300660 \mathrm{i} \\
-0.397010-0.217444 \mathrm{i} \\
-0.397010+0.217444 \mathrm{i} \\
-0.449757 \\
0.135340
\end{gathered}
$$

\section{Modulus}

$$
\begin{aligned}
& 0.862241 \\
& 0.862241 \\
& 0.452658 \\
& 0.452658 \\
& 0.449757 \\
& 0.135340
\end{aligned}
$$

No root lies outside the unit circle, this VAR model satisfies the stability condition Source: Results from Eviews 6.

The LM test on autocorrelation suggests that each VAR model is appropriate because no further autocorrelation is found.

Table 13. LM Tests for VAR Model

Model with DLER

\begin{tabular}{lll}
\hline Lags & LM-Stat & Prob \\
\hline 1 & 14.15657 & 0.1169 \\
2 & 8.764308 & 0.4593 \\
3 & 6.932171 & 0.6442 \\
4 & 14.61168 & 0.1022 \\
5 & 9.131839 & 0.4252 \\
6 & 9.864631 & 0.3616 \\
7 & 12.62929 & 0.1801 \\
8 & 12.75983 & 0.1738 \\
\hline
\end{tabular}

\section{Model with DER}

\begin{tabular}{ccc}
\hline Lags & LM-Stat & Prob \\
\hline 1 & 11.36865 & 0.2513 \\
2 & 11.29732 & 0.2559
\end{tabular}




$\begin{array}{lll}3 & 5.665168 & 0.7729 \\ 4 & 8.880593 & 0.4484 \\ 5 & 7.967176 & 0.5375 \\ 6 & 7.414719 & 0.5940 \\ 7 & 7.309952 & 0.6049 \\ 8 & 4.334793 & 0.8880\end{array}$

Source: Results from Eviews 6.

Impulse response function is applied successively to VAR with DLER and DER, the results are presented in Figure 4 and 5 respectively.

Figure 4. Results of Impulse Response Function for VAR with DLER

Response to Cholesky One S.D. Innovations \pm 2 S.E.

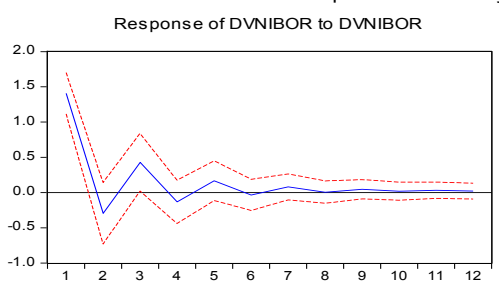

Response of DVNIBOR to DLER

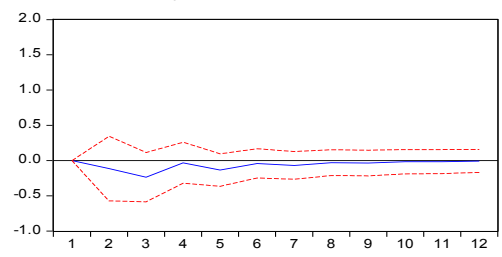

Response of DLER to DVNIBOR

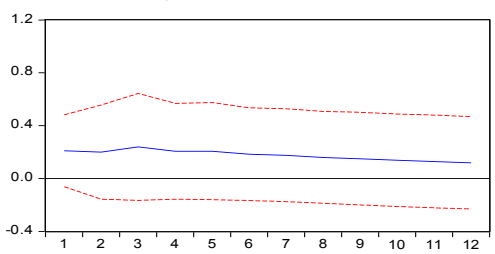

Response of DLER to DLER

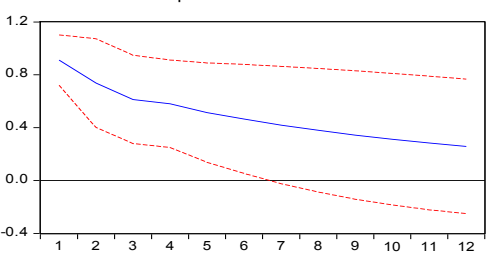

Response of DCPI to DVNIBOR
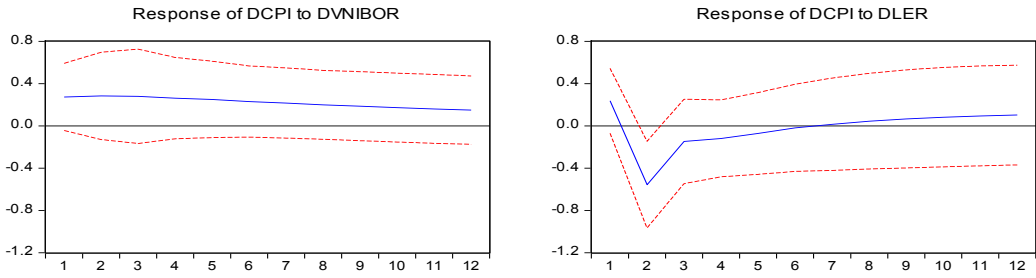

Source: Results from Eviews 6.

The results obtained from the period 2008-2013 are different from those from 2000-2007. In this period, lending rate responds vigorously to shocks of increases in monetary policy rates and tends not to cease, whereas inflation responds positively to monetary policy rates but negatively to lending rate in a short term. In other words, 
shock-generating increases in monetary policy rates lead to short-term increases in market rates and falls in inflation rate. This reflects a short-term existence of IRC during the crisis. Long-term increases in inflation along with increases in monetary policy rates might be subject to the cost channel in monetary transmission. Regarding borrowing rates offered by commercial banks, the impulse respond function produces the following results.

Figure 5. Results of Impulse Response Function for VAR with DER

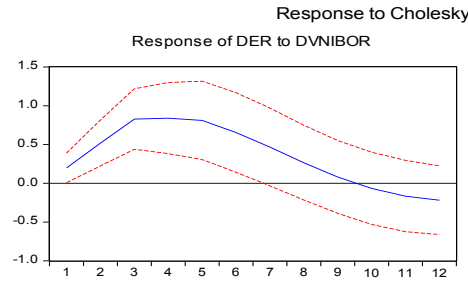

Response of DER to DER
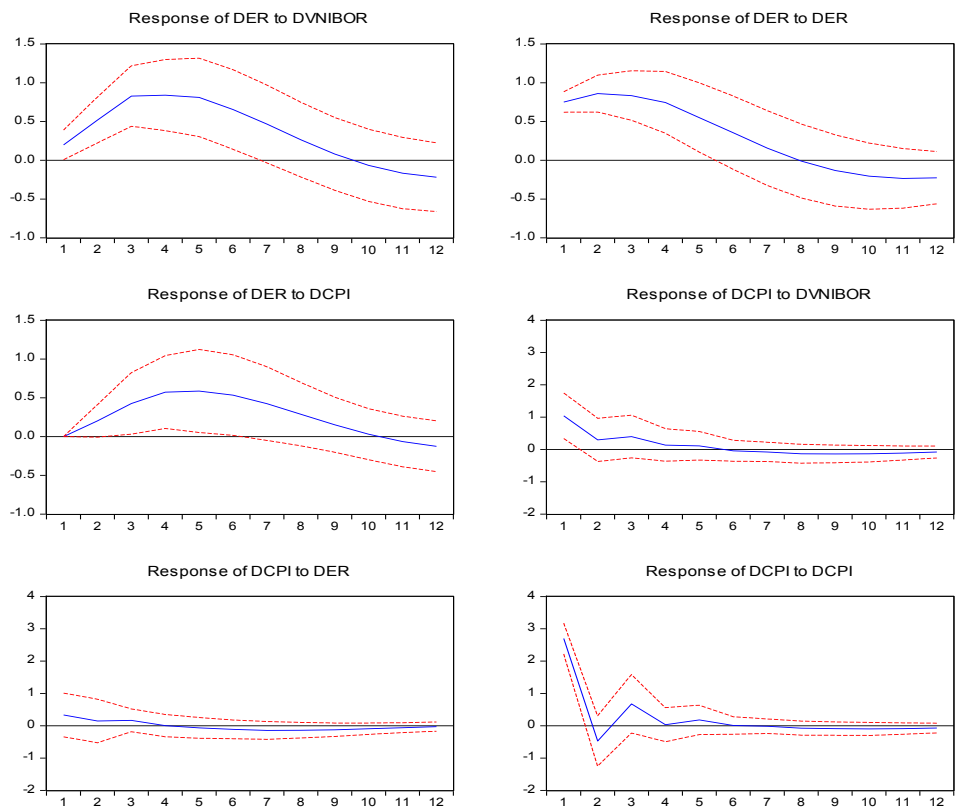

Source: Results from Eviews 6.

The IRC reflected in borrowing rates in the period 2008-2013 also reveals some results partly similar to and partly different from result produced by the IRC in the lending rate channel, which implies that inflation positively responds to shockgenerating increases in monetary policy rates and gradually descends until a cessation in the sixth term. On the other hand, borrowing rate forcefully responds to shock in monetary policy rates but fades in a long run.

In sum, IRC changed quite dramatically after the crisis in comparison with that before the crisis. It also accompanies cost channel in monetary transmission (increased interest rate leads to increased inflation). 


\section{CONCLUSION AND POLICY RECOMMENDATION}

\subsection{Conclusion:}

The VAR model shows that:

- Before the crisis, IRC exists in accordance with the theory in the context of Vietnam through both lending and borrowing rates by commercial banks. Inflation decreases when monetary policy rates increase. Monetary transmission though IRC takes place quickly and ceases after around five months.

After the crisis, monetary policy rates are no longer transmitted significantly through lending and borrowing rates as theoretically suggested. When shockgenerating increases in monetary policy rates take place, both lending and borrowing rates increase, whereas inflation also even increases instead of decreasing. Hence, increased monetary policy rates results in increased inflation, which indicates that the cost channel in monetary policy exists in the period 2008-2013. Study by Tillmann (2008) concerning the new-Keynesian Phillips curve suggests that higher interest rates increase the marginal cost of production and inflation in Britain. Other studies also confirm that monetary policy affects demand side of the economy by changing the real rates thereby affecting investment and consumption in all sectors; while Barth \& Ramey (2001) considers the effect on the supply side or cost channel of transmission mechanism. By such, the authors recommend an expansion of this research in the future to clarify the cost channel in monetary transmission in Vietnam.

\subsection{Policy Recommendation:}

From the above research results, in order that monetary policy in Vietnam can be well implemented to achieve the set goals especially in the current period, these following issues should be taken into account:

Interest rate policy affects borrowing and lending rates of commercial bank system after the crisis although it is not transmitted as vigorously as it was before and comes up with a certain lag. Therefore, the SBV, in regulating and changing interest rate policy, should anticipate the impact of monetary policy shocks on market rates and depositors and borrowers. During the crisis when increased policy rates causes market rates and production cost to rise, the SBV, instead of raising interest rates, should stabilize monetary policy rates, which will yield better effects.

However, in the present context, interest rates tend to drop for credit growth; SBV should frequently control the market rates when setting borrowing rate ceiling to 
minimize the risk of reflation. Between 2011 and 2013, interest rates were lowered to help firms access bank loans. In such conditions, the SBV should have controlled lending and borrowing rates in compliance with monetary policy to avoid adverse responses and guarantee a drop in these rates as well as firms' input costs, thereby stimulating production in the economy

\section{References}

Allen, F. \& D. Gale (2000), Comparing Financial Systems, The MIT Press.

Allen, F. \& D. Gale (2004), "Comparative Financial Systems: A Discussion”, in Bhattacharya S., A. Boot \& A. Thakor (2004) (eds.), Credit, Intermediation, and the Macroeconomy: Models and Perspectives, Oxford University Press, Oxford, New York, 699-770.

Barth, M.J. \& V.A. Ramey (2001), “The Cost Channel of Monetary Transmission”, in Bernanke, B. \& K. Rogoff (Eds.), NBER Macroeconomics Annual, 16: 199-240.

Bernanke, B.S. \& A.S. Blinder (1992), "The Federal Funds Rate and the Channels of Monetary Transmission”, American Economic Review, 82: 901-921.

Buigut, S. (2009), "Monetary Policy Transmission Mechanism: Implications for the Proposed East African Community (EAC) Monetary Union" available at $<$ http://www.csae.ox.ac.uk/conferences/2009-EDiA/papers/300-Buigut.pdf., retrieved on October 21, 2013>.

Buttiglone, L., P. DelGiovane \& O. Tristani (1997), "Monetary Policy Actions and the Term Structure of Interest Rates: A Cross-Country Analysis”, in Angeloni, I. \& R. Rovelli (ed.), Monetary Policy and Interest Rates, New York, St. Martin Press.

Cecchetti, S. (1995), "Distinguishing Theories of the Monetary Transmission Mechanism. Review", Federal Reserve Bank of St. Louis, 77: 83-97.

Cook, T. \& T. Hahn (1989), "The Effect of Changes in the Federal Funds Rate Target on Market Interest Rates in the 1970s", Journal of Monetary Economics, 24, 331-351.

Dabla-Norris, E. \& H. Floerkemeier (2006), "Transmission Mechanisms of Monetary Policy in Armenia: Evidence from VAR Analysis”, IMF Working Paper (WP/06/248), Issue Washington, DC.

Disyatat, P., P. Vongsinsirikul (2003), "Monetary Policy and the Transmission Mechanism in Thailand", Journal of Asian Economics, 14: 389-418.

Engert, W., F.L. Nott \& J. Selody (1999), "Restructuring the Canadian Financial System: Explanations and Implications", in The Monetary and Regulatory Implications of Changes in the Banking Industry, Basle: Bank for Internat. Settlements, ISBN 9291310964, 142-167.

Evans, C. \& D. Marshall (1998), "Monetary Policy and the Term Structure of Nominal Interest Rates: Evidence and Theory", Carnegie-Rochester Conference Series on Public Policy, 49: 53-111.

Favero, C., F. Iacone \& M. Pifferi (1996),"Monetary Policy, Forward Rates and Long Rates: Does Germany Differ from the Unites States?”, CEPR Working Paper No. 1456. 
Friedman, M. (1956), "The Quality Theory of Money: A Restatement”, in Friedman, M. (1956), Studies in the Quantity Theory of Money, Chicago University Press, Chicago.

Haldane, A. \& V. Read (2000), "Monetary Policy Surprises and the Yield Curve", Working Paper No.106. Bank of England.

Hannan, T.H. \& J.N. Liang (1993), "Inferring Market Power from Time-series Data: The Case of the Banking Firm”, International Journal of Industrial Organization, 11(2): 205-218.

Honda, Y. (2004), "Bank Capital Regulations and the Transmission Mechanism“, Journal of Policy Modeling, Vol.26 (6): 675-688.

Kuttner, K. (2001), "Monetary Policy Surprises and Interest Rates: Evidence from the Fed Funds Future Market”, Journal of Monetary Economics, 47: 523-544.

Lico Júnior, R. de Paula (2008), Dictionary of Financial and Business Terms, $1^{\text {st }}$ ed., McGraw-Hill.

Lindberg, H., K. Mitlid \& P. Sellin (1997), "Monetary Tactics with an Inflation Target: The Swedish Case", BIS Conference Papers - Implementation and Tactics of Monetary Policy: Bank for International Settlements, Basle, 3: 231-249.

Mengesha , L. \& M. Holmes (2013), "Monetary Policy and its Transmission Mechanisms in Eritrea", Journal of Policy Modeling, 35(5): 766-780.

Mugume, A. (2011), "Monetary Transmission Mechanisms in Uganda”, The Bank of Uganda Journal, 4(1): $3-57$

Mukherjee, S. \& R. Bhattacharya (2011), "Inflation Targeting and Monetary Policy Transmission Mechanisms in Emerging Market Economies”, IMF Working Paper (WP/11/229).

Ramlogan, C. (2007), "Mechanism of Monetary Policy in Small Developing Countries: An Application to Trinidad and Tobago", Journal of Developing Areas, 41: 79-91.

Ries, W. (2012), "Do Credit Channel and Interest Rate Channel Play Important Role in Monetary Transmission Mechanism in Indonesia?: A Structural Vector Autoregression Mode", Procedia Social and Behavioral Sciences, 65: 557-563.

Romer, C. \& D. Romer (1990), "New Evidence on the Monetary Transmission Mechanism", Brookings Papers on Economic Activity, (1): 149-198.

Sims, C. (1980), "Macroeoconomics and Reality", Econometrica, 48: 1-48.

Sims, C. (1992), "Interpreting the Macroeconomic Time-Series Facts: The Effects of Monetary Policy”, European Economic Review, 36: 975-1011.

Taylor, J. (1995), "The Monetary Transmission Mechanism: An Empirical Framework", Journal of Economic Perspectives, 9(4): 11-26.

Tillmann, P. (2008), "Do Interest Rates Drive Inflation Dynamics? An Analysis of the Cost Channel of Monetary Transmission”, Journal of Economic Dynamics \& Control, 32: 2723-2744. 